\title{
Grand Round
}

\section{Mycobacterium paratuberculosis cervical lymphadenitis, followed five years later by terminal ileitis similar to Crohn's disease}

\author{
John Hermon-Taylor, Nick Barnes, Chris Clarke, Caroline Finlayson
}

Mycobacterium paratuberculosis was first described by Johne and Frothingham in $1895^{1}$ as the cause of a chronic inflammatory disease of the intestine in a German cow. The organism was called Johne's bacillus, and the illness (in which millions of acid fast mycobacteria were visible in the diseased tissues), Johne's disease. In 1901 Thomas Dalziel, a surgeon at the Western Infirmary in Glasgow, operated on a colleague with chronic inflammation of the intestine. He was aware of the description of Johne's disease and of the subsequent bacteriological research in the field. He collected other cases and published his observations in the $B M J$ in $1913 .{ }^{2}$ He wrote that the "histological characters" of the disease he had described in humans were so similar to those of Johne's disease that the diseases may be the same. Dalziel's dilemma was that he could not see acid fast mycobacteria in the diseased intestine in humans. ${ }^{3}$

$M$ paratuberculosis belongs to the $M$ aviumintracellulare group. ${ }^{4}$ The term paratuberculosis suggests close similarity to $M$ tuberculosis, but in truth it is very different. Unlike $M$ tuberculosis, it can survive in the environment and is highly resistant in vivo to most standard antituberculous drugs. M paratuberculosis cannot be reliably detected by culture in the laboratory; different subtypes of the organism with different preferred hosts ${ }^{56}$ range from very slow growing to unculturable.

$M$ paratuberculosis can cause chronic inflammation of the intestine in many species of animals including primates. ${ }^{7-9}$ The disease in animals shows a broad range of histopathological types, from a pluribacillary (lepromatous) form with millions of typical acid fast bacilli visible in the tissues, to a paucimicrobial (tuberculoid) form in which $M$ paratuberculosis cannot be seen in the tissues and cannot be detected by culture but in which there is a florid chronic granulomatous inflammatory response. ${ }^{10}$ Intermediate paucibacillary forms of the disease, in which only a few acid fast mycobacteria may be visible, also occur.

$M$ paratuberculosis has only rarely been cultured in the laboratory from humans with chronic inflammation of the intestine of the Crohn's disease type. ${ }^{11-15}$ When it has been grown, the organism has first appeared in the culture in an unrecognisable non-bacillary form, taking months or years of incubation to alter its phenotype to that of a mature bacillus with an established lipid rich cell wall able to be identified by conventional means. Detection and characterisation of $M$ paratuberculosis has been advanced by the advent of DNA based methods that use as their target a 1451bp DNA insertion element IS900, of which there are about 16 copies stably integrated into the $M$ paratuberculosis genome. ${ }^{16}$

\section{The clinical case}

In September 1988 a healthy boy aged 7 years 10 months developed enlarged lymph nodes on the right side of his neck. He was asymptomatic and had a negative result on the Mantoux test, and chest radiography was normal. He had not had a BCG vaccination. He was referred to the surgical service at Addenbrooke's Hospital, where the enlarged lymph nodes were removed. The histological picture suggested a mycobacterial infection. Samples of the diseased lymph nodes were incubated on Lowenstein-Jensen slopes with duplicates including pyruvate, but not mycobactin, for 12 weeks at room temperature, $30^{\circ} \mathrm{C}$ and $37^{\circ} \mathrm{C}$. For two months he was treated with rifampicin $450 \mathrm{mg}$ and isoniazid $150 \mathrm{mg}$ once daily and pyrazinamide $250 \mathrm{mg}$ three times daily, but when the cultures were negative drug treatment was stopped. The remaining lymph nodes on the right side of the neck progressively enlarged and were removed by block dissection in November 1989. Mycobacterial culture again proved negative. He remained well until March 1993 when he developed an arthritis affecting both knees, and an anaemia refractory to iron. By the end of 1993, he had daily abdominal pain, anorexia, 2-3 loose bowel motions a day, weight loss, and lethargy.

His weight was $37 \mathrm{~kg}$ (on the 30 th centile) and his height $1.53 \mathrm{~m}$. He looked pale and ill and had angular stomatitis. Firm lymph nodes were still palpable on the right side of the neck. There was no clubbing. In the

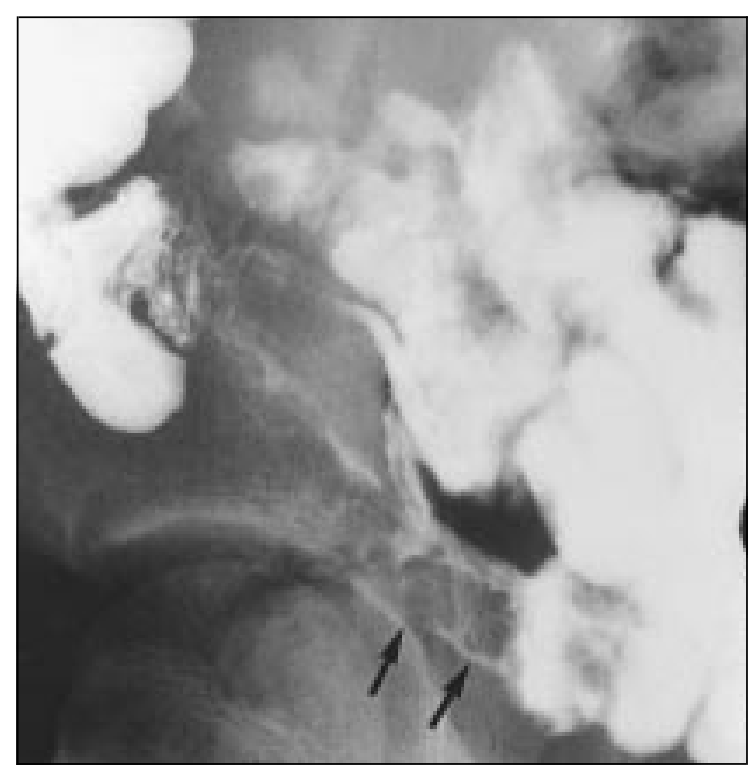

Fig 1 Narrowing and distortion of $10 \mathrm{~cm}$ segment of terminal ileum with classic "cobblestoning" of the mucosa (arrowed). The appearances are the same as those seen in Crohn's disease
Department of Surgery, St George's Hospital Medical School, London SW17 ORE

John

Hermon-Taylor, professor of surgery

Children's Services, Addenbrooke's Hospital, Cambridge CB2 2QQ

Nick Barnes, consultant paediatrician

Department of Veterinary Pathology, University of Edinburgh, Veterinary Field Station, Easter Bush, Roslin, Midlothian EH25 9RG

Chris Clarke, senior lecturer in veterinary pathology

Department of Histopathology, St George's Hospital Medical School

Caroline Finlayson, consultant senior lecturer in

histopathology

Correspondence to: Professor

Hermon-Taylor

BMJ 1998;316:449-53 
abdomen, an enlarged, tender loop of bowel was easily felt in the right iliac fossa. Radiologically, the small gut showed narrowing and distortion of a $10 \mathrm{~cm}$ segment of terminal ileum and prominent "cobblestoning" of the mucosa (fig 1). A white cell scan at one hour showed intense uptake of the label over the affected intestine (fig 2 (left)). These findings were considered typical of Crohn's disease.

He was treated daily with rifabutin $300 \mathrm{mg}$ and clarithromycin $500 \mathrm{mg}$ and was advised to have UHT ("long life") milk only. Eight days after the start of treatment lymph nodes on the left side of the neck and residual nodes on the right became enlarged and firm, with surrounding oedema. At the same time he had a transient episode of subacute intestinal obstruction, which subsided on conservative management. With continued rifabutin and clarithromycin treatment the nodes gradually subsided. By mid-1994 after six months' treatment he was virtually asymptomatic, and he was completely so by February 1995, by which time his weight had increased to $49 \mathrm{~kg}$ and his height to $1.60 \mathrm{~m}$. White cell scanning then showed a complete resolution of the previously inflamed gut (fig 2 (right)). However, he was beginning to get obstructive symptoms. A barium enema showed no active disease, but there was a tight stricture of the terminal ileum with upstream dilatation. A limited resection was therefore carried out, with removal of the terminal ileum and adjacent ascending colon for a pale fibrotic stricture followed by end to end anastomosis. The histology of the resected stricture will be described. There was no other visible evidence of inflammatory disease throughout the gut.

Treatment with rifabutin and clarithromycin and restriction to UHT milk was continued. The drugs were stopped at the end of October 1996 after a total of 32 months' treatment. By January 1997 his weight was $67 \mathrm{~kg}$ (80th centile) and his height was $1.70 \mathrm{~m}$. He was asymptomatic and a well developed adolescent on physical examination.
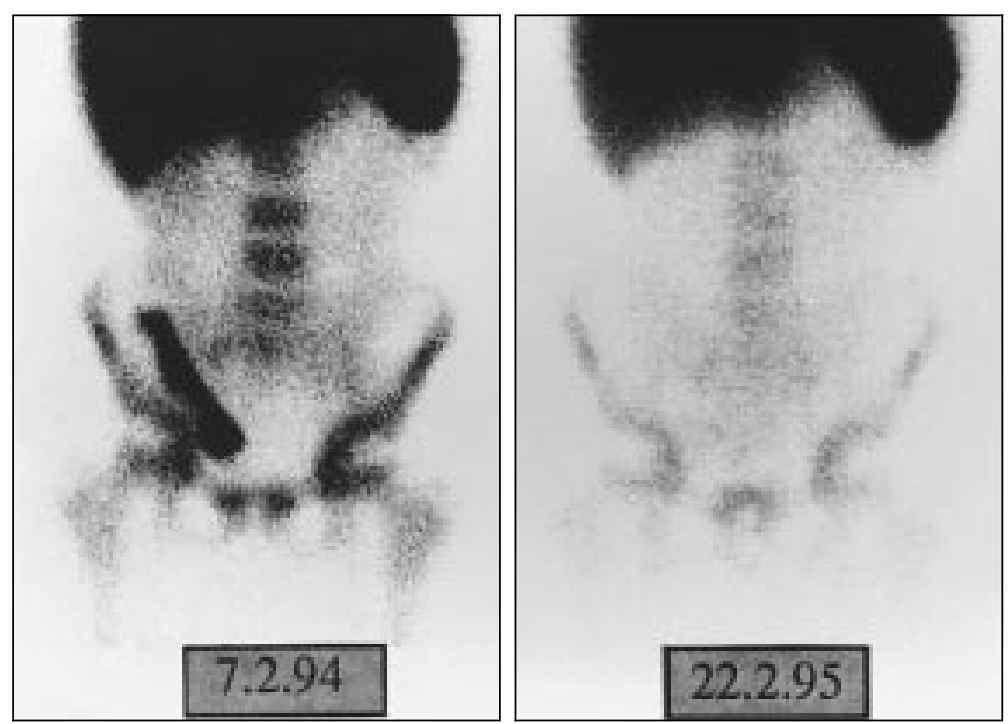

Fig 2 Left: White cell scan before treatment showing uptake of labelled cells by inflamed ileum characteristic of Crohn's disease. Right: White cell scan after one year of chemotherapy using combination of rifabutin and clarithromycin, showing apparent complete resolution
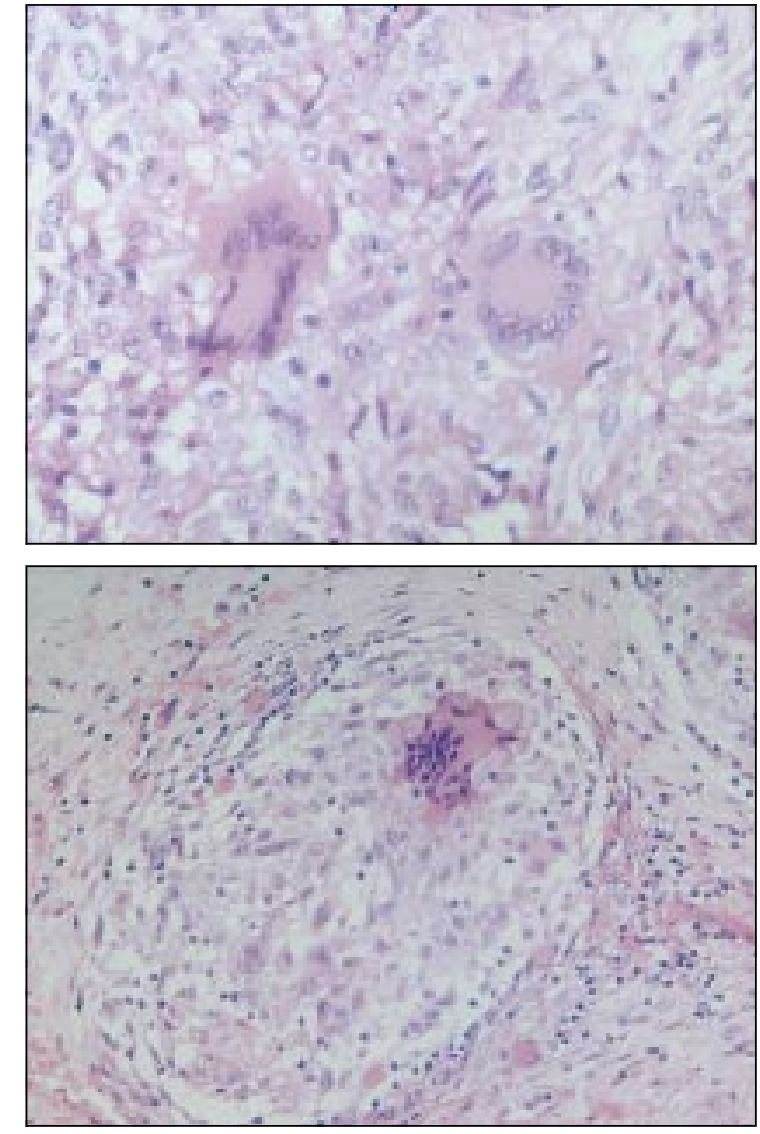

Fig 3 Microscopical appearance (top, $\times 400$; bottom, $\times 250$ ) of enlarged cervical lymph nodes showing typical Langerhans' giant cells with epithelioid cells, together with a non-caseating granuloma

\section{Histopathology}

Sections of the cervical lymph nodes initially removed showed areas of typical caseous necrosis with a only a few acid fast bacilli visible on Ziehl-Neelsen staining. Elsewhere there were marked chronic inflammatory changes with typical Langerhans' giant cells, noncaseating granulomata and an epithelioid cell infiltrate with focal microcalcifications (fig 3). The macroscopical appearances at operation were of a white fibrous stricture $5 \mathrm{~mm}$ in diameter and about $20 \mathrm{~mm}$ long in the terminal ileum (fig 4 (top), with encroachment of fat over the serosal surface. There was no evidence of chronic inflammatory disease elsewhere in the gut. Microscopically the mucosa over the ileal stricture was intact with little gland distortion and villous atrophy, but the submucosa and gut wall showed extensive transmural fibrosis. There was no evidence of active inflammatory disease or granulomata (fig 4 (bottom)). The mesenteric lymph nodes showed reactive hyperplasia but were otherwise normal.

\section{Identification of $M$ paratuberculosis by IS900 polymerase chain reaction}

Two of the paraffin embedded cervical lymph nodes removed in 1988 (fig 5) were subjected to DNA extraction using standard protocols and simultaneous process controls. IS 900 polymerase chain reaction for $M$ paratuberculosis was then performed on the DNA extract in triplicate using the primers p90 (5'GAAGGGTGTTCGGGGCCGTCGCTTAGG-3') and 

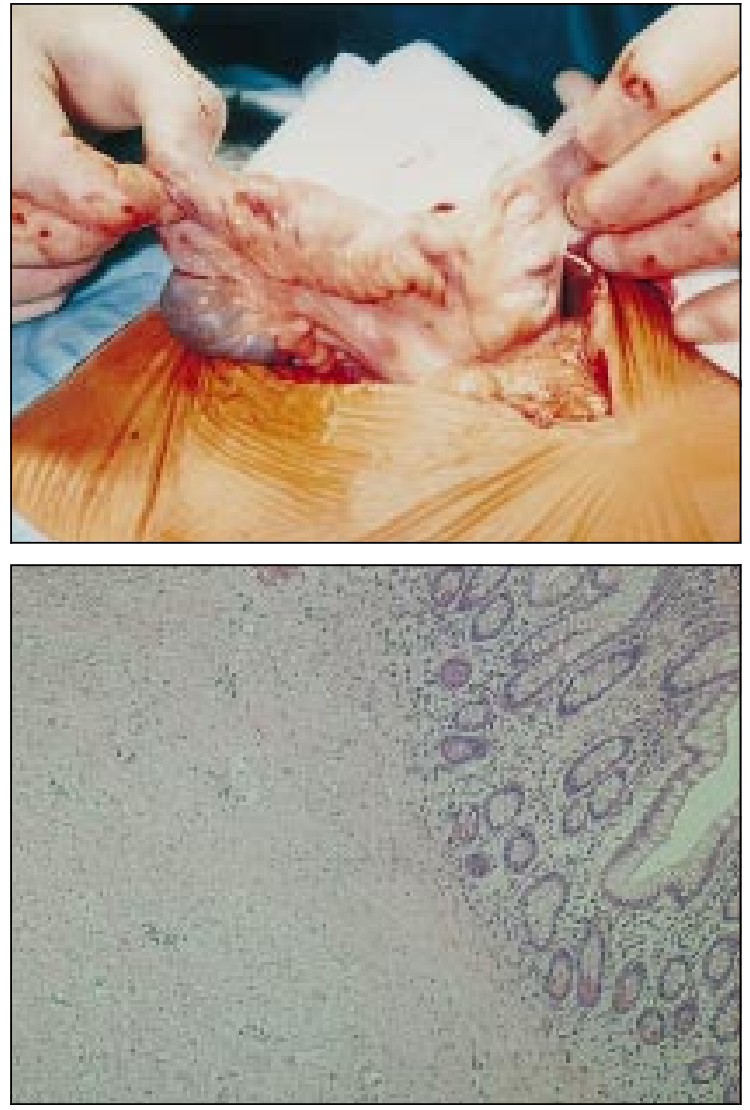

Fig 4 Top: lleal stricture that developed after one year of treatment with rifabutin and clarithromycin. Bottom: Microscopical appearance $(\times 100)$ of ileal stricture showing extensive intramural fibrosis

p91 (5'-GGCGTTGAGGTCGATCG CCCACGTGAC$\left.3^{\prime}\right){ }^{18}$ Amplification products were run on agarose gel electrophoresis and identified by hybridisation at high stringency using a ${ }^{32} \mathrm{P}$ labelled $229 \mathrm{bp}$ internal probe followed by autoradiography, as previously described. ${ }^{18}$ The DNA extract of the cervical lymph nodes was strongly positive in triplicate for $M$ paratuberculosis in the presence of negative process controls and correctly reporting positive and negative internal polymerase chain reaction controls (fig 6). The strongly positive signal from the IS 900 polymerase chain reaction that was obtained on the crude DNA extract from the cervical lymph nodes without hybridisation capture of target $\mathrm{DNA}^{18}$ probably reflects a relatively high microbial abundance of $M$ paratuberculosis in the tissues at an early stage of the infection.

\section{Comment}

\section{$M$ paratuberculosis infections in animals}

Among animals, Johne's disease, or M paratuberculosis infection, occurs in domestic ruminants, especially cattle, sheep, and goats. Studies at the San Diego zoo and elsewhere, however, have shown that a broad range of animals, including subhuman primates, can be affected. ${ }^{8}$

Recently, $M$ paratuberculosis has been identified in wild rabbits in Tayside, Scotland. ${ }^{19}$ In subclinically infected cows $M$ paratuberculosis is secreted abundantly in the milk, so that infection is acquired early in the life of newborn calves, when they are particularly susceptible. ${ }^{20}$ The gut is the main target organ; $M$ paratuberculosis is shed in the faeces, but it can travel throughout the

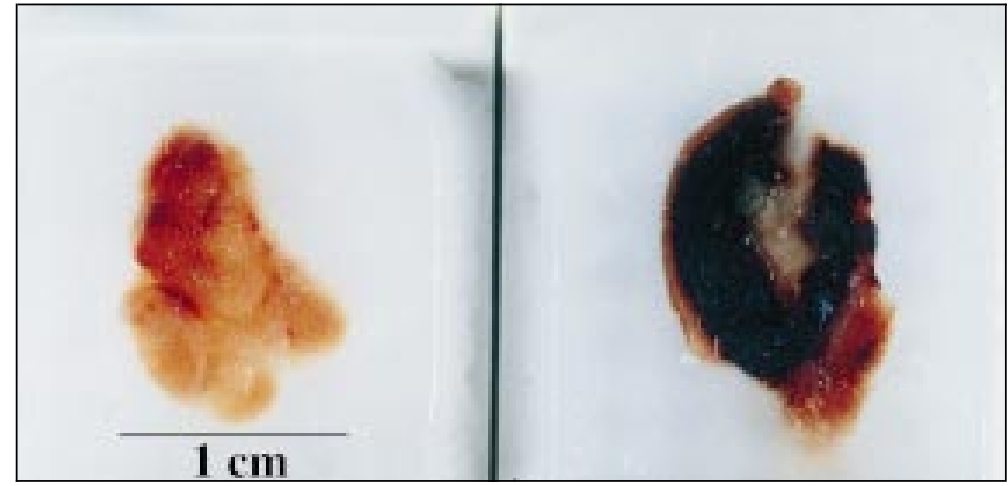

Fig 5 Enlarged paraffin embedded cervical lymph nodes removed in September 1988 from which DNA extract was prepared

animal in macrophages. A long latent interval usually occurs before clinical disease emerges. The signs of the disease in cattle are weight loss and diarrhoea; diarrhoea is not common in sheep. The pathology of the pluribacillary "lepromatous" type of disease is a chronic enteritis with diffuse thickening of the gut wall especially the terminal ileum, but extension to involve the colon is common. Mesenteric lymph nodes are enlarged. The mucosa of the gut is reddened with crevicing and marked oedema but not usually ulceration. Microscopically, there are millions of small acid fast M paratuberculosis living in macrophages (fig 7(a)).

We have shown that in about one quarter of cases there is a different form of Johne's disease in sheep. ${ }^{10}$ Although the clinical signs and gross pathology are similar, microscopically there is a pronounced chronic granulomatous enteritis with heavy lymphocytic infiltration, typical Langerhans'-type giant cells and scattered granulomata. A few nests of acid fast bacteria can be found in about half of these cases of "tuberculoid" Johne's disease (fig 7 (b)). In the others, no bacillary form $M$ paratuberculosis is visible in the tissues at all (fig 7 (c) and (d)).

\section{Transmission of $M$ paratuberculosis to humans}

In the early part of this century, when milk supplies were at times heavily contaminated with $M$ tuberculosis and $M$ bovis, ${ }^{21}$ tuberculous cervical lymphadenitis was common. The organism entered through not only the

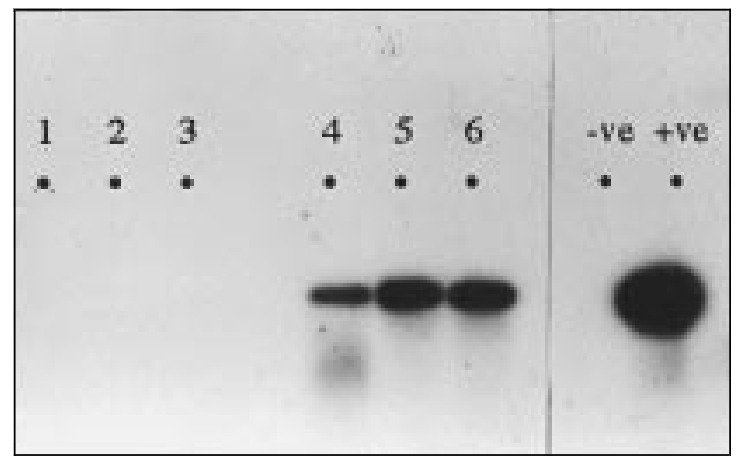

Fig 6 Results of IS900 polymerase chain reaction with amplification products analysed by agarose gel electrophoresis and autoradiography. Lanes 1, 2, and 3 are simultaneous process controls correctly reporting negative; lanes 4,5 , and 6 are the DNA extract from the enlarged nodes showing strongly positive triplicate reactions for Mycobacterium paratuberculosis; and on the right are negative and positive (10fg Mptb target DNA) internal polymerase chain reaction controls 

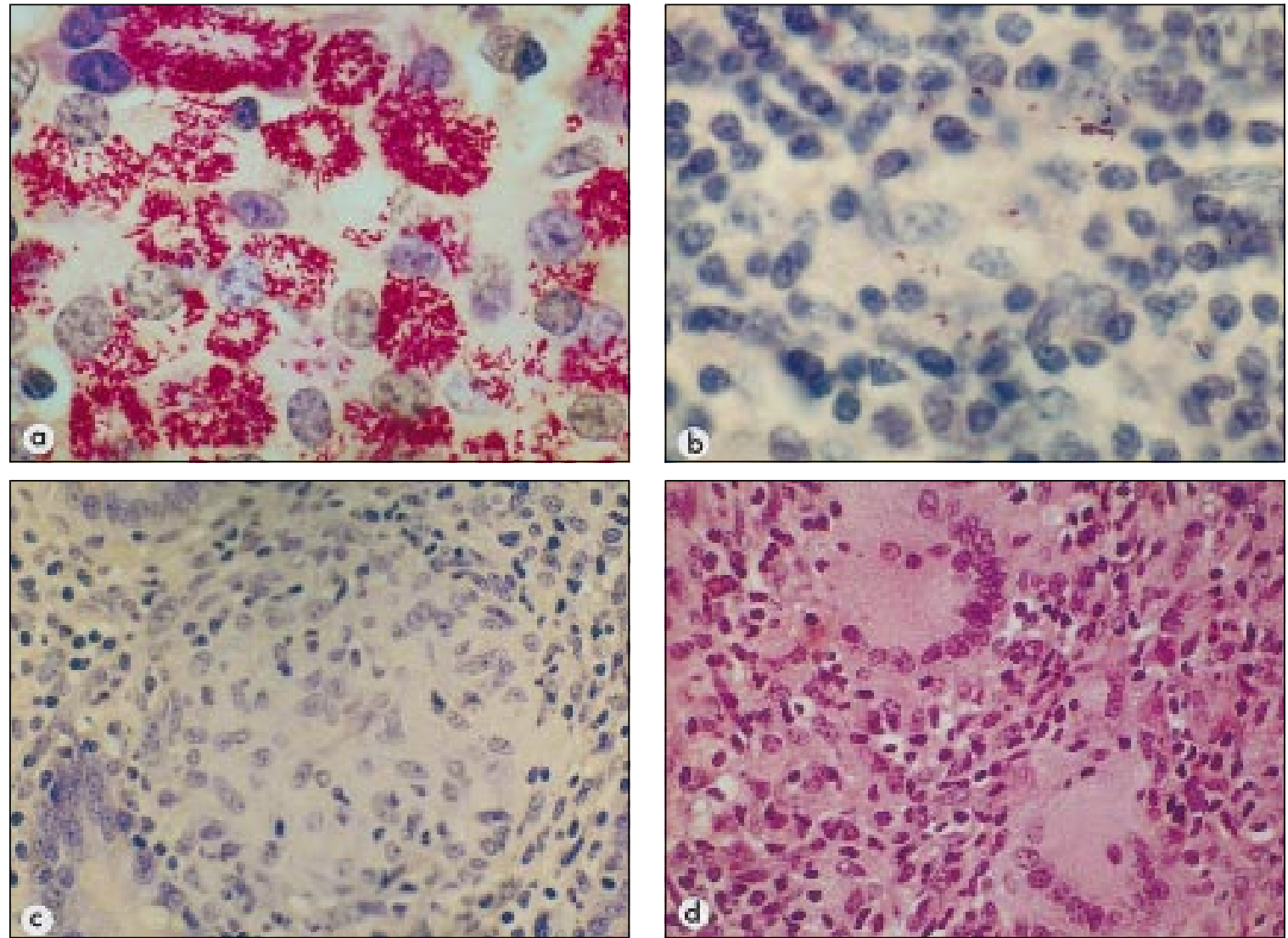

Fig 7 Photomicrographs of sections of intestinal wall, illustrating range of histological appearances and abundance of visible $M$ paratuberculosis organisms in infected sheep with different forms of Johne's disease: (a) Ziehl-Neelsen stain ( $\times 1600)$ showing classic pluribacillary Johne's disease in which large numbers of small, acid fast $M$ paratuberculosis organisms are seen within macrophages, but with little chronic granulomatous response; (b) Ziehl-Neelsen stain ( $\times 1600)$ showing paucibacillary form of Johne's disease with scant $M$ paratuberculosis visible in tissues and prominent lymphocytic infiltration; (c) Ziehl-Neelsen stain ( $\times 800)$ of paucimicrobial form of Johne's disease diagnosed by IS900 poymerase chain reaction, in which no bacillary form M paratuberculosis can be seen; (d) haematoxylin and eosin stain $(\times 800)$ of paucimicrobial Johne's disease in a sheep showing typical Langerhans' giant cells and pronounced chronic granulomatous inflammation.

oropharyngeal lymphoid tissues but also the gut, causing tuberculous ileitis and disease in other parts of the body. The problem was overcome by tuberculin testing of dairy herds and the mandatory introduction of milk pasteurisation, using conditions that ensured the destruction of these well recognised pathogens.

The risk that something similar is happening with $M$ paratuberculosis is substantial, although the organism is much less virulent for humans than is M tuberculosis. ${ }^{22}$ Subclinical infection of dairy cows with $M$ paratuberculosis is widespread in Britain and elsewhere in Europe, ${ }^{23}$ and such animals shed the organism in their milk. ${ }^{20} 22$ Conditions in the laboratory simulating commercial pasteurisation, which demonstrably kill $M$ bovis do not always kill the more environmentally robust $M$ paratuberculosis. ${ }^{24}{ }^{25}$ Outcomes analysis of the treatment of humans with chronic enteritis of the Crohn's disease type with a combination of drugs predicted to be active against non-bacillary forms of $M$ paratuberculosis in vivo suggests that the use of such a drug combination can cause substantial remission in many patients with active Crohn's disease. ${ }^{26}$

The young boy in this case was probably infected by milk contaminated with non-tuberculous mycobacteria including $M$ paratuberculosis. The organisms would have entered his cervical lymph nodes and his terminal ileum, as also occurs in animals. ${ }^{27}$ After a latent interval of about five years, first an arthritis and then a chronic enteritis emerged. This was similar clinically, radiologically, and on white cell scanning, to Crohn's disease. Shortly after starting to take rifabutin and clarithromycin he had a transient flare of the disease, with widespread enlargement of the cervical lymph nodes, and an episode of subacute intestinal obstruction, similar to disease exacerbations reported in some cases of leprosy and tuberculosis after treatment is started. ${ }^{28} 29$ In this case, the gut healed with prolonged treatment, leaving a scar that needed excision.

\section{Discussion}

Angus Dalgleish: As $M$ tuberculosis is associated with caseation and M paratuberculosis is not, could both have been involved?

CF: The involvement of $M$ tuberculosis is unlikely as it was not cultured from the lymph nodes, and the boy had a negative result on the Mantoux test. Other organisms such as $M$ scrofulaceum can cause caseation in cervical lymph nodes. The information we have on this boy suggests that this was a mixed, nontuberculous mycobacterial infection, which on this occasion also included $M$ paratuberculosis in considerable abundance. We do not of course see caseation in the intestinal lesions of Crohn's disease.

George Griffin: Why do we not all get Crohn's disease? 
JH-T: Probably for the same reasons that not everybody got tuberculosis earlier this century. In addition, $M$ paratuberculosis has a much lower pathogenicity for humans than $M$ tuberculosis. Several susceptibility factors are required for chronic enteritis and clinical disease due to $M$ paratuberculosis to develop. These include firstly, an inherited susceptibility ${ }^{30}$ well known in Crohn's disease clinically, especially among Jewish people ${ }^{31}$ but possibly also in Celtic races. An understanding of the molecular genetics of susceptibility is just beginning to emerge. . $^{32-34}$ Secondly, intercurrent microbial infection (particularly gastroenteritis) is well known to be associated with the emergence of Crohn's disease. Lastly, psychological stress factors ${ }^{35}$ which are known to be able to trigger the emergence of Johne's disease in animals, may be associated with both the development of Crohn's disease and its exacerbation.

Devinder Kumar: If $M$ paratuberculosis is a ubiquitous environmental organism how do you explain the geographical distribution of Crohn's disease?

JH-T: The environmental distribution of $M$ paratuberculosis is not known. Efficient farming methods in industrialised societies, however, may have created localised conditions favouring the amplification of $M$ paratuberculosis in our domestic livestock and their controlled habitats over the course of the century. Persistence of the pathogen would be favoured in temperate regions with a high water table. ${ }^{36}$ Such conditions may also have increased the mutational frequency of $M$ paratuberculosis and resulted in the emergence of a strain with increased pathogenicity for humans.

Robert Boyd: There is clearly a need for a randomised controlled trial of treatment with rifabutin and clarithromycin in patients with Crohn's disease.

NB: This certainly seems to be the case. A trial in children would seem to be particularly appropriate because they present relatively early on during the course of the disease, before they have developed the irreversible tissue damage and the range of complications that often occurs in adults.

George Griffin is professor of medicine, Angus Dalgleish is professor of oncology, Robert Boyd is principal, and Devinder Kumar is consultant surgeon at St George's Hospital Medical School, London.

We thank Jon Ford for assistance, and Drs Alan Grundy and Alan Freeman for their advice. The DNA extraction and polymerase chain reaction on the cervical lymph nodes was performed by Dr Douglas Millar. CC currently works in the department of pathology at GlaxoWellcome Research and Development, Ware, Hertfordshire SG12 0DP.

Funding: Astra Pharmaceuticals sponsored the grand rounds meeting. Research into Mycobacterium paratuberculosis in the department of surgery at St George's Hospital Medical School has been supported by Action Research, the Dinwoodie Trust, the Colt Foundation, the Ileostomy Association, and the Wellcome Trust. The study in milk was also supported by the Ministry of Agriculture, Fisheries and Food.

Conflict of interest: JH-T has prosecuted patents on IS900 and would share with coworkers in a proportion of revenues generated by the successful commercial exploitation and use of this technology.

1 Johne HA, Frothingham L. Ein eigenthuemlicher Fall von Tuberkulose beim Rind. Deutsche Zeitschrift für Tiermedicin und Pathologie 1895;21:43854.

2 Dalziel TK. Chronic interstitial enteritis. BMJ 1913;ii:1068-70.

3 Hermon-Taylor J, Moss M, Tizard M, Malik S, Sanderson J. Molecular biology of Crohn's disease mycobacteria. Baillière's Clin Gastroenterol 1990;4:23-42.

4 Boddinghaus B, Wolters J, Heikens W, Böttger EC. Phylogenetic analysis and identification of different serovars of Mycobacterium intracellulare at the molecular level. FEMS Microbiol Lett 1990;70:197-203.
5 Pavlik I, Bejkova L, Pavlas M, Rozsypalova Z, Koskova S. Characterization by restriction endonuclease analysis and DNA hybridization using IS900 of bovine, ovine, caprine and human dependent strains of Mycobacterium paratuberculosis isolated in various localities. Vet Microbiol rium paratuberci $1995 ; 45: 311-8$.

6 Bauerfeind R, Benazzi S, Weiss R, Schliesser T, Willems H, Baljer G. Molecular characterization of Mycobacterium paratuberculosis isolates from sheep, goats, and cattle by hybridization with a DNA probe to insertion element IS900. J Clin Microbiol 1996;34:1617-21.

7 Chiodini RJ, Van Kruiningen HJ, Merkal RS. Ruminant paratuberculosis (Johne's disease): the current status and future prospects. Cornell Vet 1984;74:218-62

8 McClure HM, Chiodini RJ, Anderson DC, Swenson RB, Thayer WR, Coutu JA. Mycobacterium paratuberculosis (Johne's disease) in a colony of stump-tail macaques (Macaca arctoides). J Infect Dis 1987;155:1011-9.

9 Hines ME, Kreeger JM, Herron AJ. Mycobacterial infections of animals: pathology and pathogenesis. Lab Anim Sci 1995;45:334-51.

10 Clarke CJ, Little D. The pathology of ovine paratuberculosis: histological and morphometric changes and correlations in the intestine and other tissues. J Comp Path 1996; 114:419-437.

11 Chiodini RJ, Van Kruiningen HJ, Merkal RS, Thayer WR, Coutu JA. Characteristics of an unclassified Mycobacterium species isolated from patients with Crohn's disease. J Clin Microbiol 1984;20:966-71.

12 Coloe P, Wilkes CR, Lightfoot D, Tosolini FA. Isolation of Mycobacterium paratuberculosis in Crohn's disease. Aust Microbiol 1986;7:188A.

13 Gitnick G, Collins J, Beaman B, Brooks D, Arthur M, Imaeda T, et al. Preliminary report on isolation of mycobacteria from patients with Crohn's disease. Dig Dis Sci 1989;34:925-32.

14 Haagsma J, Mulder CJJ, Eger A, Tytgat GNJ. Mycobacterium paratuberculosis isolé chez des patients atteints de maladie de Crohn. Résultats préliminaires. Acta Endoscopica 1991;255-60.

15 Thorel M-F. Relationship between Mycobacterium avium, M paratuberculosis and mycobacteria associated with Crohn's disease. Ann Rech Vet 1989;20:417-29.

16 McFadden JJ, Butcher PD, Chiodini R, Hermon-Taylor J. Crohn's disease isolated mycobacteria are identical to Mycobacterium paratuberculosis, as determined by DNA probes that distinguish between mycobacterial species. J Clin Microbiol 1987;25:796-801.

17 Green EP, Tizard M, Moss M, Thompson J, Winterbourne DJ, McFadden $\mathrm{JJ}$, et al. Sequence and characteristics of IS900, an insertion element identified in a human Crohn's disease isolate of Mycobacterium paratuberculosis. Nucl Acids Res 1989;17:9063-73.

18 Millar DS, Withey S, Tizard M, Ford J, Hermon-Taylor J. Solid-phase hybridization capture of low-abundance target DNA sequences: application to the polymerase chain reaction detection of Mycobacterium paratuberculosis and Mycobacterium avium subsp silvaticum. Anal Biochem 1995;226:325-30.

19 Grieg A, Stevenson K, Perez V, Pirie AA, Grant JM, Sharp JM. Paratuberculosis in wild rabbits (Oryctolagus cuniculus). Vet Record 1997;140:141-3.

20 Sweeney RW, Whitlock RH, Rosenberger AK. Mycobacterium paratuberculosis cultured from milk and supramammary lymph nodes of infected asymptomatic cows. J Clin Microbiol 1992;30:166-71.

21 Humphriss E, Peden D, Wright HD. The adequacy of commercial pasteurisation for destruction of tubercle bacilli. Lancet 1937;ii:151-2.

22 Millar D, Ford J, Sanderson JD, Withey S, Tizard M, Doran T, et al. IS900 PCR to detect Mycobacterium paratuberculosis in retail supplies of whole pasteurised cows' milk in England and Wales. Appl Environ Microbiol 1996;62:3446-52.

23 Cetinkaya B, Egan K, Morgan KL. An abbattoir-based study of the prevalence of subclinical Johne's disease in adult cattle in south west England. Epidemiol Infect 1996;116:373-9.

24 Chiodini RJ, Hermon-Taylor J. The thermal resistance of Mycobacterium paratuberculosis in raw milk under conditions simulating pasteurisation. J Vet Diagn Invest 1993;5:629-31.

25 Grant IR, Ball HJ, Rowe MT. Inactivation of Mycobacterium paratuberculosis in cows' milk at pasteurization temperatures. Appl Environ Micrbiol 1996;62:631-6.

26 Gui G, Thomas P, Tizard M, Lake J, Sanderson JD, Hermon-Taylor J. Two year outcomes analysis of Crohn's disease treated with rifabutin and macrolide antibiotics. J Antimicrob Chemother 1997;39:393-400.

27 Sweeney RW, Whitlock RH, Hamir AN, Rosenberger AK, Herr SA. Isolation of Mycobacterium paratuberculosis after oral inoculation in uninfected cattle. Am J Vet Res 1992;53:1312-4.

28 Naafs B. Reactions in leprosy. In: Ratledge C, Stanford JR, Grange JM, eds. Biology of mycobacteria. Vol 3. Amsterdam: Academic Press, 1989:359-81.

29 Choremis CB, Padiatellis C, Zoumboulakis D, Yannakos D. Transitory exacerbation of fever and roentgenographic findings during treatment of tuberculosis in children. Ann Rev Tuberc 1955;72:527-36.

30 Sachar DB. Crohn's disease: a family affair. Gastroenterol 1996;111:813-

31 Roth M-P, Petersen GM, McElree C, Feldman E, Rotter JI. Geographic origins of Jewish patients with inflammatory bowel disease. Gastroenterol 1989;97:900-4.

32 Hugot J-P, Laurent-Puig P, Gower-Rousseau C, Olson JM, Lee JC, Beaugerie L, et al. Mapping of a susceptibility locus for Crohn's disease on chromosome 16. Nature 1996:379:821-3.

33 Plevy SE, Targan SR, Yang H. Fernandez D, Rotter JI, Toyoda H. Tumor necrosis factor microsatellites define a Crohn's disease-associated haplotype on chromosome 6. Gastroenterol 1996;110:1053-60.

34 Forcione DG, Sands B, Isselbacher KJ, Rustgi A, Podolsky DK, Pillai S. An increased risk of Crohn's disease in individuals who inherit the HLA class II DRB3*0301 allele. Proc Natl Acad Sci USA 1996;93:5094-8.

35 Cohen S, Williamson GM. Stress and infectious disease in humans. Psycholog Bull 1991;109:5-24.

36 Collins CH, Grange JM, Yates MD. Mycobacteria in water.J Appl Bacteriol 1984;57:193-211. 